\title{
Sealing ability of MTA, CPM, and MBPc as root- end filling materials: a bacterial leakage study
}

\author{
Paulo Leal MEDEIROS ${ }^{1}$, Norberti BERNARDINELI', Bruno Cavalini CAVENAGO'1, Sérgio Aparecido TORRES ${ }^{2}$, Marco \\ Antonio Hungaro DUARTE ${ }^{1}$, Clovis Monteiro BRAMANTE1, Marina Angélica MARCIANO'
}

1- Universidade de São Paulo, Faculdade de Odontologia de Bauru, Departamento de Dentística, Materiais Odontológicos e Endodontia, Bauru, SP, Brasil
2- Universidade de São Paulo, Faculdade de Odontologia de Bauru, Departamento de Microbiologia e Imunologia, Bauru, SP, Brasil

Corresponding address: Marina Angélica Marciano - Faculdade de Odontologia de Bauru, Universidade de São Paulo - Al. Octávio Pinheiro Brisolla, 9-75 - 17012-901 - Bauru - São Paulo - Brazil - e-mail: marinangelica@usp.br

Submitted: January 22, 2013 - Modification: April 14, 2014 - Accepted: June 12, 2014

\section{ABSTRACT}

$\mathrm{O}$ bjectives: To evaluate the sealing ability of three root-end filling materials (white MTA, CPM, and MBPC) using an Enterococcus faecalis leakage model. Material and Methods: Seventy single-root extracted human teeth were instrumented and root-ends were resected to prepare $3 \mathrm{~mm}$ depth cavities. Root-end preparations were filled with white MTA, CPM, and MBPc cements. Enterococcus faecalis was coronally introduced and the apical portion was immersed in $\mathrm{BHI}$ culture medium with phenol red indicator. The bacterial leakage was monitored every $24 \mathrm{~h}$ for 4 weeks. The statistical analysis was performed using the Wilcoxon-Gehan test $(p<0.05)$. Results: All cements showed bacterial leakage after 24 hours, except for the negative control group. The MBPc showed significantly less bacterial leakage compared with the MTA group $(p<0.05)$. No significant differences were found between the CPM and the other groups. Conclusions: The epoxy resin-based cement MBPC had lower bacterial leakage compared with the calcium silicate-based cements MTA and CPM.

Keywords: Endodontics. Dental pulp cavity. Epoxy resins.

\section{NTRODUCTI ON}

Persistent microorganisms are the main factors associated with chronic apical periodontitis and consequent Endodontic failures ${ }^{10}$. One of the indications for periradicular surgery is when the conventional treatment is not able to eliminate the microorganisms of the apical portion?. These procedures involve the use of filling materials to prevent bacterial leakage and the reinfection of the root canal system ${ }^{27}$. Therefore, it is crucial for the cement used to obturate root-end cavities to be able to provide a tridimensional filling.

Several materials were suggested for retrograde fillings, e.g., amalgam, EBA, IRM, gutta-percha, and $M_{T A}{ }^{2,32}$. The Mineral Trioxide Aggregate (MTA) is currently used in retrograde fillings, showing satisfactory physicochemical ${ }^{15,29}$ and biological properties ${ }^{28,30}$. Other cements are studied as alternatives for the MTA. In 2004, a novel rootend filling material comparable with the MTA was developed. The CPM (EGEO SLR, MTM Argentina
SA, Buenos Aires, Argentina) is composed of a powder mainly made of Portland cement and a liquid with distilled water in its composition. The CPM cement presents antimicrobial activity ${ }^{23}$, satisfactory biological response ${ }^{18,20}$, and adequate physicochemical properties ${ }^{4,24}$.

Epoxy-resin based cements have been widely studied for Endodontic procedures since 19578,19. In 1984, Moraes and Berbert developed an epoxy resin-based cement containing calcium hydroxide to be used as a retrograde filling material ${ }^{13}$. The MBPC is consisted of hydrophobic base paste/catalyst paste cement ${ }^{14}$. Promissory results regarding its physical $^{34}$, chemical ${ }^{14,33}$, and biological ${ }^{3,9}$ properties were found. Nonetheless, this cement requires more investigation to be considered clinically useful.

There are several methods to evaluate the sealing ability of filling materials such as fluid infiltration ${ }^{34}$, radioisotope ${ }^{22}$, dye penetration ${ }^{6,14}$, and bacterial leakage ${ }^{21}$. Radioisotope and dye penetration methods present the disadvantage of having the molecular size of radioisotopes tracers 
and dye particles smaller than bacteria ${ }^{31}$. On the other hand, bacterial leakage is considered more clinically relevant ${ }^{31}$. This method is widely used in Endodontic research to evaluate the sealing ability of root canal sealers ${ }^{12,26}$ and root-end filling materials ${ }^{1,11}$. A previous study has compared MTA, CPM, and MBPC cements using a dye penetration model $^{14}$. Considering the limitations of this method, it is indispensable for us to investigate if there is bacterial infiltration in root-end fillings with these cements. Thus, the aim of the study was to evaluate the sealing ability of three root-end filling materials (white MTA, CPM, and MBPc) using an Enterococcus faecalis leakage model.

\section{MATERI AL AND METHODS}

Seventy intact, caries-free, single-rooted permanent human teeth were selected. The ethics committee of the Bauru School of Dentistry approved the use of teeth for research purposes (CEP 049-2007). All teeth were autoclaved. The coronal portions were sectioned $1.0 \mathrm{~mm}$ below the dental-enamel junction using a $0.3 \mathrm{~mm}$ Isomet saw (Buehler, Lake Bluff, Illinois, USA). Roots were standardized at $15 \mathrm{~mm}$ and the working length (WL) was established $1.0 \mathrm{~mm}$ from the apical foramen. Root canals were prepared using the crowndown technique with K-files (Dentsply Maillefer, Ballaigues, Switzerland). Apical preparation was performed at working length up to a size $40 \mathrm{~K}$-file. The shaping procedure was completed with 2 and 3 Gates-Glidden drills (Dentsply Maillefer, Ballaigues, Switzerland). After the use of each instrument, we irrigated the canal with $2 \mathrm{~mL}$ of $2.5 \%$ sodium hypochlorite. The smear layer was removed with $2 \mathrm{~mL}$ of $17 \%$ EDTA (Biodinâmica, Ibiporã, Paraná, Brazil) for three minutes, then a $2 \mathrm{~mL}$ flush of distilled water was used as the final rinse and the canals were dried with paper points (DentsplyMaillefer). The final $3.0 \mathrm{~mm}$ of each root was resected with a cylindrical diamond bur, perpendicularly to the long axis of the root. A root-end cavity with $3.0 \mathrm{~mm}$ of depth and $1.0 \mathrm{~mm}$ of diameter was prepared. A gutta-percha cone of size 40.02 was inserted into the root canal $3 \mathrm{~mm}$ from the final of the root to provide an intracanal matrix to pack the root-end filling material against.

\section{Root-end filling}

The specimens were randomly divided in three groups $(n=20)$ : Brazil);

Group 1: MTA (Angelus, Londrina, Paraná,

Group 2: CPM (Egeo, Buenos Aires, Argentine); Group 3: MBPc.

The composition of the evaluated cements is present in Figure 1. Cements were manipulated by following the manufacturer's instructions. They were incrementally inserted into the rootend cavities and vertically compacted using a hand plugger. Specimens were stored in $100 \%$ of humidity at $37^{\circ} \mathrm{C}$ for one week to allow the cements to set. For negative control $(n=5)$, the entire root surface was coated with two layers of nail varnish (Colorama, L'Oréal, São Paulo, São Paulo, Brazil) after filling all root-end cavities. Positive control $(n=5)$ was left with unfilled root-end cavities.

\section{Bacterial leakage}

The apparatus used to evaluate the leakage was prepared as previously described ${ }^{21}$. Glass vials with rubber stoppers were adjusted to use. Using a high-speed handpiece, a hole was made through the centre of each rubber stopper in which each tooth was inserted under a pressure up to $4 \mathrm{~mm}$ from the apical portion. An epoxy resin-based varnish (Araldite, Brascola, São Paulo, São Paulo, Brazil) was used to seal the interface between tooth and rubber stopper. Cylinders prepared with $10 \mathrm{~mL}$ plastic syringes were adapted to the outer surface of the stoppers to create a chamber around the crown of the tooth. The apparatus was sterilized in ethylene oxide gas for a $4 \mathrm{~h}$ cycle at $56^{\circ} \mathrm{C}$ (Figure 2 ).

The standard bacterial strains of Enterococcus faecalis (ATCC 29212) were used in the study.

\begin{tabular}{|c|c|c|}
\hline \multirow{2}{*}{$\begin{array}{c}\text { Cement } \\
\text { White } \\
\text { MTA }\end{array}$} & \multicolumn{2}{|c|}{ Components } \\
\hline & Powder: & Liquid: \\
\hline & Tricalcium silicate & Distilled water \\
\hline & Dicalcium silicate & \\
\hline & Tricalcium aluminate & \\
\hline & $\begin{array}{l}\text { Tetracalcium } \\
\text { aluminoferrite }\end{array}$ & \\
\hline & Bismuth oxide & \\
\hline \multirow[t]{6}{*}{ CPM } & Base: & Catalyst: \\
\hline & Calcium carbonate & $\begin{array}{c}\text { Sterile saline } \\
\text { solution }\end{array}$ \\
\hline & Bioxide of silicium & \\
\hline & Trioxide of bismuth & \\
\hline & Barium sulphate & \\
\hline & Insoluble particles & \\
\hline \multirow[t]{5}{*}{ MBPc } & Base: & Catalyst: \\
\hline & Calcium hidroxyde & Barium sulphate \\
\hline & Barium sulphate & $\begin{array}{l}\text { Subnitrate of } \\
\text { bismuth }\end{array}$ \\
\hline & Subnitrate of bismuth & Epoxy resin \\
\hline & Epoxy resin & $\begin{array}{c}\text { Vegetal mamona } \\
\text { polymer }\end{array}$ \\
\hline
\end{tabular}

Figure 1- Composition of the evaluated cements 
The Brain Heart Infusion Medium (BHI, Difco, BD Diagnostic Systems, Sparks, Maryland, USA) was used for bacterial growth. Enterococcus faecalis was inoculated in tubes containing $5 \mathrm{~mL}$ of sterile $\mathrm{BHI}$ suspension and incubated at $37^{\circ} \mathrm{C}$ for 24 hours. To adjust the experimental suspensions, turbidity of culture microorganisms were verified with an spectrophotometer (1105, Bel Photonics do Brasil Ltda., Osasco, Brazil) at 540 nm, bacterial cells were resuspended according to the MacFarland scale to obtain a final concentration of $3 \times 10^{8}$ colony-forming units (CFU) $/ \mathrm{mL}$. The purity of the cultures was confirmed by the Gram staining method and the morphology of the colony.

Sterile pipettes were used to place $400 \mu \mathrm{l}$ of bacterial inoculum in each access cavity found in the syringe apparatuses (in the upper region, removing the gauze stop). The $4 \mathrm{~mm}$ of root-ends were immersed in sterile BHI. The apparatus was incubated at $37^{\circ} \mathrm{C}$ for 120 days and checked daily for turbidity in the BHI broth. Bacterial leakage was considered when turbidity was observed (Table 1).

\section{Statistical analysis}

Statistical analysis was performed using the Wilcoxon-Gehan test to compare the evaluated groups $(p<0.05)$.

\section{RESULTS}

The criteria evaluated with experimental periods are shown in Figure 3. All cements showed bacterial leakage after 24 hours, except for the negative control group. The MTA showed a higher number of specimens that leaked compared with the MBPC group ( $p<0.05)$. Statistical similarities for bacterial leakage were found between the CPM and the MBPC and also the MTA ( $p>0.05)$. After 31 days until the final period, only one specimen (MBPc) among all groups showed infiltration.

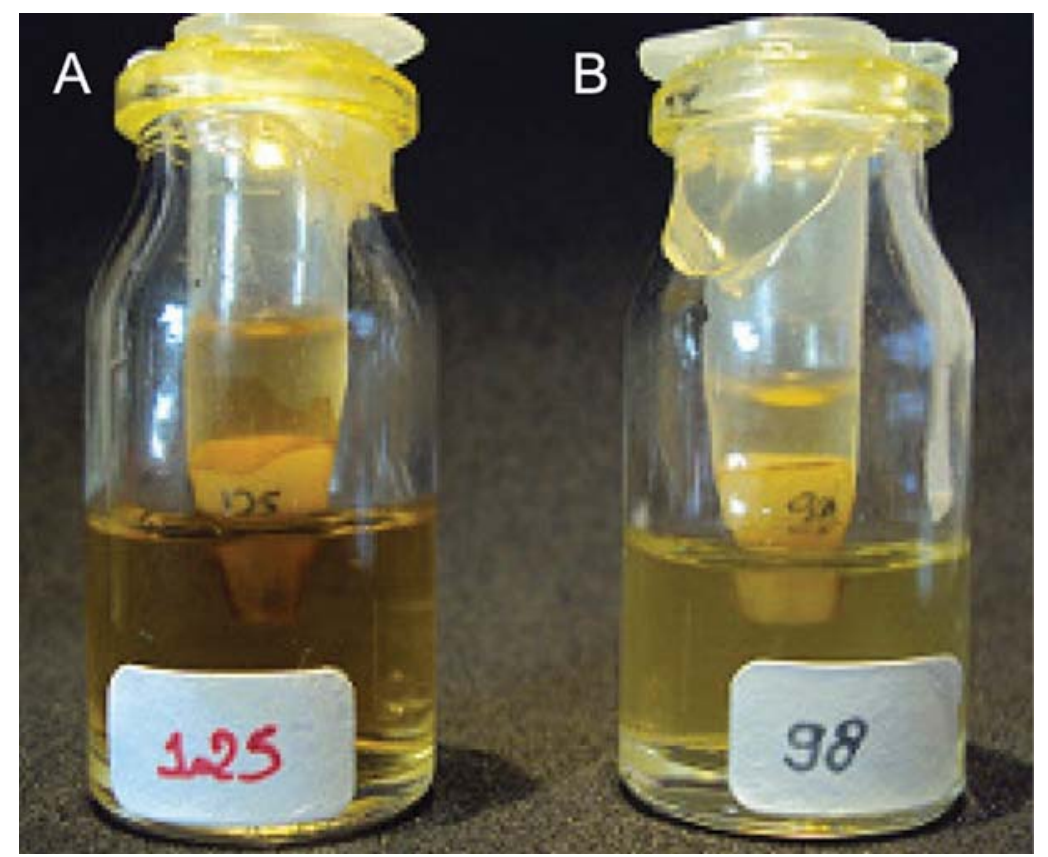

Figure 2- Representative leakage apparatus used for the experiment. Negative microbial growth is shown in $A$ and positive microbial growth can be observed in B

Table 1- Number of samples with positive bacterial leakage every 30 days

\begin{tabular}{|c|c|c|c|c|c|c|}
\hline Cement & $\begin{array}{l}\text { Total of } \\
\text { samples }\end{array}$ & $1-30$ days & $31-60$ days & $61-90$ days & $91-120$ days & Total \\
\hline White MTA & 20 & 7 & 0 & 0 & 0 & 7 \\
\hline CPM & 20 & 4 & 0 & 0 & 0 & 4 \\
\hline $\mathrm{MBPc}$ & 20 & 1 & 0 & 1 & 0 & 2 \\
\hline Positive control & 5 & 5 & 0 & 0 & 5 & 5 \\
\hline $\begin{array}{c}\text { Negative } \\
\text { control }\end{array}$ & 5 & 0 & 0 & 0 & 0 & 0 \\
\hline
\end{tabular}




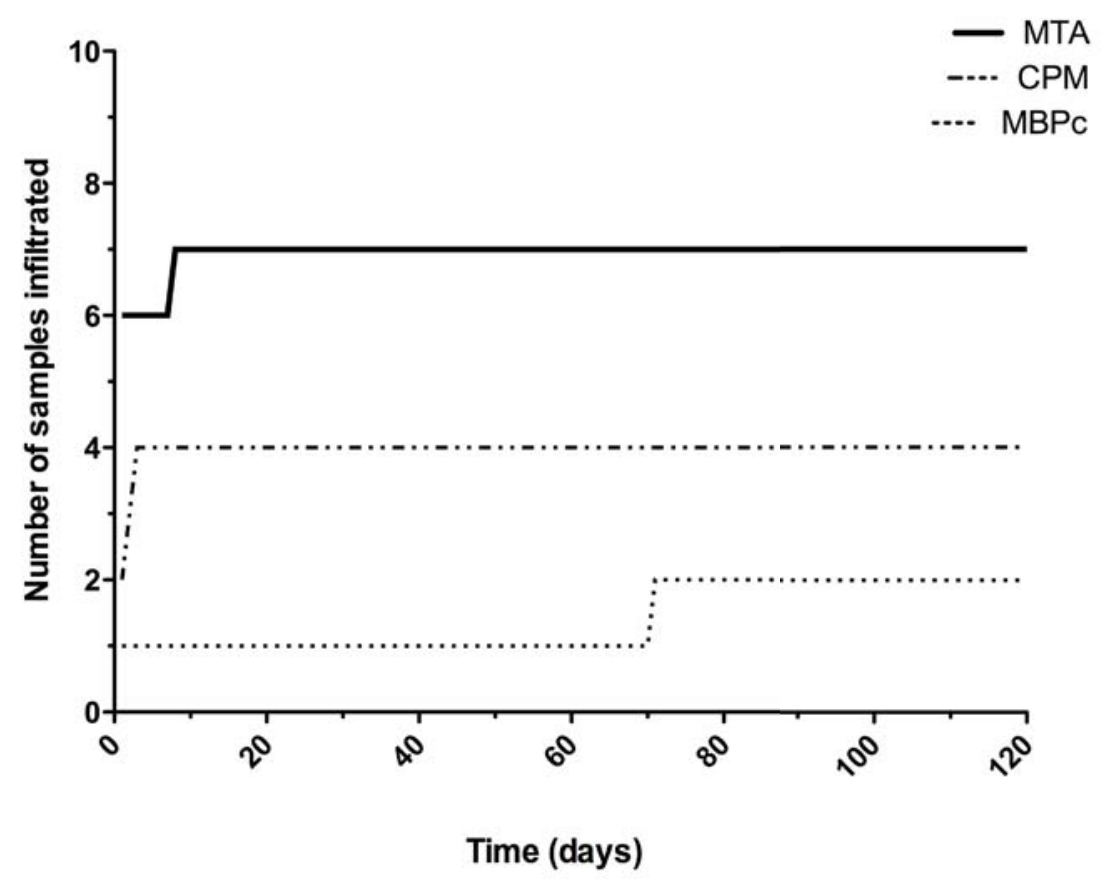

Figure 3- Number of samples leaked during a period of 120 days

\section{DISCUSSION}

The success of retrograde fillings concerns the properties of the cement used ${ }^{17}$. The aim of root-end filling materials is to adhere to the dentine of the apical portion difficulty bacterial leakage providing conditions to periapical healing ${ }^{32}$. The sealing ability of a cement can be determined using leakage methods ${ }^{12,14}$, confocal microscopy ${ }^{32}$, scanning electron microscopy ${ }^{25}$, and more recently microcomputed tomography analysis ${ }^{35}$. The bacterial leakage method has the advantage of providing a clinically relevant adaptability date of materials for root canal walls ${ }^{31}$.

The Enterococcus faecalis was chosen for this study model because it is commonly present in secondary infections from Endodontic treatment failures. This microorganism is a gram-positive coccus and is highly resistant to alkaline $\mathrm{pH}$ such as the one present in the calcium hydroxide paste. Because of its high incidence in filled root canals and their drug resistance, the E. faecalis has been proposed as an Endodontic pathogen ${ }^{16}$. Furthermore, this microorganism is easily arranged and interpreted from the study data ${ }^{11}$. Under the conditions of this study, this microorganism was able to leak in all experimental cements. On the other hand, Jacobovitz, et al. ${ }^{5}$ (2009), using another model of in vitro microleakage analysis with the same microorganism, found that the MTA showed no microbial growth after 30 days.

The results found in the present study showed that the bacterial leakage occurred after 24 hours in at least one specimen for MTA, CPM, and MBPC cements. During the experimental period, all groups showed decrease in the number of leaked specimens. A possible explanation is that the cements expanded into the cavities during the period and difficult the leakage. The results found in the present study are according to that previously found by Orosco, et al. ${ }^{35}$ (2008), although they have used the dye penetration method.

Although no statistical differences were found between MBPc and CPM cements $(p>0.05)$, the MBPc showed statistically less infiltration compared with the MTA $(p<0.05)$. In a previous study, the MBPc showed satisfactory results for marginal adaptation and leakage ${ }^{14}$. Vasconcelos, et al. ${ }^{34}$ (2011) reported low leakage ranges for epoxyresin sealers $\mathrm{MBPC}$ and $\mathrm{AH}$ Plus compared with the MTA, using a fluid infiltration method. Possibly the presence of epoxy-resin improved the sealing of $\mathrm{MBPC}$ and $\mathrm{AH}$ Plus in dentin walls.

The modified Portland cement (CPM) contains calcium carbonate, silicon dioxide, bismuth trioxide, and barium sulphate ${ }^{33}$. Probably, the presence of calcium carbonate could be the responsible for offering a great calcium ions release, which may promote the adhesion to dentinal canal walls, thus improving sealing properties ${ }^{33}$. According to the results, this cement has not been able to inhibit bacterial leakage completely. The absence of studies evaluating the CPM makes difficult the comparison regarding its sealing ability.

Further studies should use the confocal laser scanning (CLSM) microscopy to detect and quantify bacterial viability in void spaces or gaps between cavity walls. Moreover, prospective clinical 
studies evaluating the success rate of Endodontic surgeries using the tested sealers might prove to be informative.

\section{CONCLUSI ON}

The epoxy resin-based cement MBPc had lower bacterial leakage compared with the calcium silicate-based cements MTA and CPM.

\section{REFERENCES}

1- Adamo HL, Buruiana R, Schertzer L, Boylan RJ. A comparison of MTA, Super-EBA, composite and amalgam as root-end filling materials using a bacterial microleakage model. Int Endod $\mathrm{J}$. 1999;32(3):197-203.

2- Beltes P, Zervas P, Lambrianidis T, Molyvdas I. In vitro study of the sealing ability of four retrograde filling materials. Endod Dent Traumatol. 1988;4(2):82-4.

3- Cintra LT, Moraes IG, Estrada BP, Gomes-Filho JE, Bramante CM, Garcia RB, et al. Evaluation of the tissue response to MTA and MBPC: microscopic analysis of implants in alveolar bone of rats. J Endod. 2006;32(6):556-9.

4- Guerreiro-Tanomaru JM, Duarte MA, Goncalves M, TanomaruFilho M. Radiopacity evaluation of root canal sealers containing calcium hydroxide and MTA. Braz Oral Res. 2009;23(1):119-23. 5- Jacobovitz M, Vianna ME, Pandolfelli VC, Oliveira IR, Rossetto $\mathrm{HL}$, Gomes BP. Root canal filling with cements based on mineral aggregates: an in vitro analysis of bacterial microleakage. Oral Surg Oral Med Oral Pathol Oral Radiol Endod. 2009;108(1):140-4. 6- Leonardo MV, Goto EH, Torres CR, Borges AB, Carvalho CA, Barcellos DC. Assessment of the apical seal of root canals using different filling techniques. J Oral Sci. 2009;51(4):593-9.

7- Lopes HP, Siqueira JF Junior. Endodontics: biology and techniques. Rio de Janeiro: MEDSI; 1999.

8- Marciano MA, Ordinola-Zapata R, Cunha TV, Duarte MA, Cavenago BC, Garcia RB, et al. Analysis of four gutta-percha techniques used to fill mesial root canals of mandibular molars. Int Endod J. 2011;44(4):321-9.

9- Miranda RB, Fidel SR, Boller MA. L929 cell response to root perforation repair cements: an in vitro cytotoxicity assay. Braz Dent J. 2009;20(1):22-6.

10- Nair PN, Sjogren U, Krey G, Kahnberg KE, Sundqvist G. Intraradicular bacteria and fungi in root-filled, asymptomatic human teeth with therapy-resistant periapical lesions: a longterm light and electron microscopic follow-up study. J Endod. $1990 ; 16(12): 580-8$.

11- Nair U, Ghattas S, Saber M, Natera M, Walker C, Pileggi R. A comparative evaluation of the sealing ability of 2 root-end filling materials: an in vitro leakage study using Enterococcus faecalis. Oral Surg Oral Med Oral Pathol Oral Radiol Endod. 2011;112(2):e74-7.

12- Oliveira ACM, Tanomaru JM, Faria-Junior N, Tanomaru-Filho M. Bacterial leakage in root canals filled with conventional and MTA-based sealers. Int Endod J. 2011;44(4):370-5.

13- Orosco FA, Bramante CM, Garcia RB, Bernadineli N, Moraes IG. Sealing ability of grar MTA AngelusTM, CPM TM and MBPc used as apical plugs. J Appl Oral Sci. 2008;16(1):50-4.

14- Orosco FA, Bramante CM, Garcia RB, Bernardineli N, Moraes IG. Sealing ability, marginal adaptation and their correlation using three root-end filling materials as apical plugs. J Appl Oral Sci. 2010;18(2):127-34.

15- Parirokh M, Torabinejad M. Mineral trioxide aggregate: a comprehensive literature review--Part I: chemical, physical, and antibacterial properties. J Endod. 2010;36(1):16-27.

16- Pinheiro ET, Gomes BP, Ferraz CC, Sousa EL, Teixeira FB, Souza-Filho FJ. Microorganisms from canals of root-filled teeth with periapical lesions. Int Endod J. 2003;36(1):1-11.
17- Pitt Ford TR, Roberts GJ. Tissue response to glass ionomer retrograde root fillings. Int Endod J. 1990;23(5):233-8.

18- Scarparo RK, Haddad D, Acasigua GA, Fossati AC, Fachin EV, Grecca FS. Mineral trioxide aggregate-based sealer: analysis of tissue reactions to a new endodontic material. J Endod. 2010;36(7):1174-8.

19- Silva GF, Guerreiro-Tanomaru JM, Sasso-Cerri E, TanomaruFilho M, Cerri PS. Histological and histomorphometrical evaluation of furcation perforations filled with MTA, CPM and ZOE. Int Endod J. $2011 ; 44(2): 100-10$.

20- Schroeder A. Endodontics - science and practice: a textbook for student and practioner. Chicago: Quintessence; 1981.

21- Siqueira JF Jr., Rocas IN, Abad EC, Castro AJ, Gahyva SM, Favieri A. Ability of three root-end filling materials to prevent bacterial leakage. J Endod. 2001;27(11):673-5.

22- Szeremeta-Browar TL, VanCura JE, Zaki AE. A comparison of the sealing properties of different retrograde techniques: an autoradiographic study. Oral Surg Oral Med Oral Pathol. 1985;59(1):82-7.

23- Tanomaru JM, Tanomaru-Filho M, Hotta J, Watanabe E, Ito IY. Antimicrobial activity of endodontic sealers based on calcium hydroxide and MTA. Acta Odontol Latinoam. 2008;21(2):147-51. 24- Tanomaru-Filho M, Faleiros FB, Sacaki JN, Duarte MA, Guerreiro-Tanomaru JM. Evaluation of $\mathrm{pH}$ and calcium ion release of root-end filling materials containing calcium hydroxide or mineral trioxide aggregate. J Endod. 2009;35(10):1418-21.

25- Tanzilli JP, Raphael D, Moodnik RM. A comparison of the marginal adaptation of retrograde techniques: a scanning electron microscopic study. Oral Surg Oral Med Oral Pathol. 1980;50(1):7480.

26- Tasdemir T, Yildirim T, Buruk K, Celik D, Cora S, Tahan E, et al. Comparison of the sealing ability of three filling techniques in canals shaped with two different rotary systems: a bacterial leakage study. Oral Surg Oral Med Oral Pathol Oral Radiol Endod. 2009 [cited 2016 Jan 20];108(3):e129-34. Available from: http:// dx.doi.org/ 10.1016/j.tripleo.2009.05.007.

27- Torabinejad M, Higa RK, McKendry DJ, Pitt Ford TR. Dye leakage of four root end filling materials: effects of blood contamination. J Endod. 1994;20(4):159-63.

28- Torabinejad M, Hong CU, Lee SJ, Monsef M, Pitt Ford TR. Investigation of mineral trioxide aggregate for root-end filling in dogs. J Endod. 1995;21(12):603-8.

29- Torabinejad M, Hong CU, McDonald F, Pitt Ford TR. Physical and chemical properties of a new root-end filling material. J Endod. 1995;21(7):349-53.

30- Torabinejad M, Parirokh M. Mineral trioxide aggregate: a comprehensive literature review--part II: leakage and biocompatibility investigations. J Endod. 2010;36(2):190-202. 31- Torabinejad M, Rastegar AF, Kettering JD, Pitt Ford TR. Bacterial leakage of mineral trioxide aggregate as a root-end filling material. J Endod. 1995;21(3):109-12.

32- Torabinejad M, Watson TF, Pitt Ford TR. Sealing ability of a mineral trioxide aggregate when used as a root end filling material. J Endod. 1993;19(12):591-5.

33- Vasconcelos BC, Bernardes RA, Cruz SM, Duarte MA, Padilha $\mathrm{PM}$, Bernardineli $\mathrm{N}$, et al. Evaluation of $\mathrm{pH}$ and calcium ion release of new root-end filling materials. Oral Surg Oral Med Oral Pathol Oral Radiol Endod. 2009;108(1):135-9.

34- Vasconcelos BC, Bernardes RA, Duarte MA, Bramante CM, Moraes IG. Apical sealing of root canal fillings performed with five different endodontic sealers: analysis by fluid filtration. J Appl Oral Sci. $2011 ; 19(4): 324-8$

35- Zakizadeh P, Marshall SJ, Hoover CI, Peters OA, Noblett WC, Gansky SA, et al. A novel approach in assessment of coronal leakage of intraorifice barriers: a saliva leakage and microcomputed tomographic evaluation. J Endod. 2008;34(7):871-5. 